\title{
IMPLEMENTASI NILAI-NILAI KARAKTER YANG TERKANDUNG DALAM KEGIATAN EKSTRAKURIKULER PRAMUKA SDN 18 PURNAMA KECAMATAN DUMAI BARAT
}

\author{
Ina Sufriani, Zulfan Saam, Caska \\ ${ }^{1}$ Magister Administrasi Pendidikan, Program Pascasarjana Universitas Riau, \\ Pekanbaru, Indonesia \\ ${ }^{2}$ Program Studi Bimbingan Konseling, Fakultas Keguruan dan IImu Pendidikan, \\ Universitas Riau, Pekanbaru, Riau \\ ${ }^{2}$ Program Studi Pendidikan Ekonomi, Fakultas Keguruan dan IImu Pendidikan, \\ Universitas Riau, Pekanbaru, Riau \\ *zulfan.saam@lecturer.unri.ac.id
}

Received: July 05 ${ }^{\text {th }}, 2021$ Revised: August $04^{\text {th }}, 2021$ Accepted: August $10^{\text {th }}, 2021$

\begin{abstract}
Character provides an overview of a nation, as a marker of characterization, as well as differentiating a nation from another. Character is the direction of how the nation will pass through an era and deliver it to a certain degree. A great nation is a nation that has character that is able to build a civilization of Saleh, (2012: 1). Character education which is systematically applied to one of the formal school institutions, namely Elementary School (SD) is a fairly good progress. The students acquire positive behaviors and habits that can increase their self-confidence. Character education applied to formal educational institutions can also be a means of civilizing and humanizing Noviani, (2011: 205-215). Data was collected through interviews, documentation and observation. Analysis of the data in this study with the following steps: Data Reduction, Data Presentation, Conclusion Drawing and Verification From the results of data analysis carried out on the impact of scouting activities in shaping the character of discipline and responsibility, namely rewards and punishments, direct orders and directions, and conditioning for every action. The achievement of 4 indicators of discipline and responsibility in keeping the lesson schedule such as doing the assigned tasks, discipline and responsibility in respecting time, students do not procrastinate on work, especially worship, selfdiscipline and responsibility focusing on students' independence and discipline and responsibility in maintaining physical condition, namely students are able to maintain a healthy lifestyle.
\end{abstract}

Keywords: extracurricular activities; implementation of character values; scouts

\section{PENDAHULUAN}

Pendidikan karakter selain dilaksanakan pada kegiatan pramuka juga bisa dilaksanakan pada kegiatan-kegiatan di sekolah lainnya, seperti kegiatan belajar mengajar, kegiatan lomba dan lain sebagainya. Dengan cakupan yang lebih luas daripada pramuka. Seperti yang disampaikan oleh Murniyetti dkk 
(2016:158) dalam penelitiannya bahwa secara nyata mendapati bahwa terdapat delapan tema penting tentang pola pelaksanaan pendidikan karakter yang dilaksanakan terhadap siswa sekolah dasar di Kota Padang. Delapan tema tersebut dilaksanakan melalui materi pembelajaran, aturan aturan sekolah, perlombaan sains antar siswa, ajang penghargaan siswa berprestasi, peringatan hari kebangsaan, praktik ibadah harian dan bimbingan kerohanian, kegiatan pramuka, serta adanya kelas talenta dan musik.

Ekstrakurikuler merupakan kegiatan yang dilakukan guna memperluas wawasan serta peningkatan dan penerapan nilai-nilai sikap. Selain itu, kegiatan ekstrakurikuler juga merupakan salah satu cara menampung dan mengembangkan potensi siswa yang tidak tersalurkan disekolah. Salah satu kegiatan ekstrakurikuler yang sesuai dengan program sekolah dan dapat menumbuh kembangkan keterampilan anak didik serta sikap mereka adalah ekstrakurikuler pramuka.

Ekstrakurikuler pramuka saat ini dimasukkan dalam kurikulum 2013 sebagai ekstrakurikuler wajib, Gerakan Pramuka dapat berfungsi sebagai wadah pembinaan dan pengembangan generasi muda adapun pelaksanaannya disesuaikan dengan keadaan, kepetingan, dan perkembangan bangsa serta masyarakat Indonesia. Nuh (2013:27-29) menuliskan, "bahwa dalam kurikulum 2013, kepramukaan ditetapkan sebagai kegiatan ekstrakurikuler wajib dari sekolah dasar (SD/MI) hingga sekolah menengah atas (SMA/SMK), dalam pendidikan dari sekolah dasar hingga sekolah menengah atas". Tujuan ekstrakurikuler pramuka sebagai yang tak terpisahkan untuk mewujudkan tujuan nasional, seperti yang tercatum dalam Pembukaan UUD 1945 yaitu, "Melindungi segenap bangsa Indonesia dan seluruh tumpah darah Indonesia dan mewujudkan kesejahteraan umum, mencerdaskan kehidupan bangsa dan ikut melaksanakan ketertiban dunia berdasarkan perdamaian abadi, kemerdekaan dan keadilan sosial".

Kegiatan pramuka juga dapat memberikan bekal yang sangat berharga bagi terciptanya generasi muda yang tangguh (Putra, \& Hermaya, 2020; Yuliana, Putra, \& Antosa, 2020). Karena, kegiatan ekstrakurikuler ini mampu mendidik anak dalam membentuk kedisiplinan. Sikap disiplin sangat diperlukan untuk terwujudnya suatu proses belajar yang baik. Belajar dengan disiplin yang terarah dapat menghindarkan diri dari rasa malas dan menimbulkan kegairahan siswa dalam belajar, yang pada 
akhirnya akan dapat meningkatkan daya kemampuan belajar siswa. Disiplin adalah kunci sukses dan keberhasilan. Oleh karena itu ekstrakurikuler pramuka sangat penting dilaksanakan agar siswa terbiasa terdidik dengan sikap disiplin.

Kegiatan ekstrakurikuler menjadi wadah yang tepat dalam pembentukan dan pengembangan nilai-nilai karakter. Meskipun sebenarnya beberapa kurikulum telah mempersiapkan peserta didik untuk memiliki nilai-nilai karakter yang dipersyaratkan dalam tujuan pendidikan nasional. Pendidikan Agama dan Pendidikan Kewarganegaraan serta Pendidikan Seni dan Olahraga merupakan beberapa kurikulum yang menghendaki peserta didik memiliki kompetensi spiritual, kompetensi personal, kompetensi sosial dan kompetensi emosional secara seimbang. Kompetensi-kompetensi tersebut merupakan dimensi pembentukan nilainilai karakter. Salah satu organisasi ekstrakurikuler di sekolah yang sangat berperan dalam pendidikan nilai-nilai karakter adalah pramuka.

Penanaman nilai-nilai karakter harus dibangun dan dikembangkan secara sadar hari demi hari melalui suatu proses yang tidak instan. Melalui pendidikan karakter di sekolah penanaman nilai-nilai karakter bertujuan untuk meningkatkan mutu pendidikan dan hasil pendidikan di sekolah yang mengarah pada pencapaian nilai- nilai karakter dan akhlak mulia pada peserta didik secara utuh.

Penanaman nilai-nilai karakter yang mencapai keberhasilan tidak diragukan untuk masa depan bangsa sendiri akan mengalami perubahan menuju bangsa yang lebih baik. Dalam lembaga pendidikan sekolah memiliki tanggung jawab untuk menjadikan peserta didik yang mempunyai pengetahuan, keterampilan, dan mengembangkannya di dalam pendidikan formal dan non formal.

Seperti di Sekolah Dasar Negeri 018 Purnama Kecamatan Dumai Barat memberikan pendidikan nilai-nilai karakter salah satunya yang terkandung melalui kegiatan ektrakurikuler yaitu kegiatan pramuka. Kegiatan pramuka di Sekolah Dasar Negeri 018 Purnama Kecamatan Dumai Barat melibatkan semua siswa yang ada disekolah baik itu siswa kelas satu sampai dengan kelas enam dengan harapan bisa memberikan pendidikan nilai-nilai karakter dimulai dari usia dini.

Berdasarkan hasil wawancara diperoleh data awal bahwa ektrakurikuler Pramuka diadakan secara teratur dan sistematis. Pada kegiatan tersebut ditanamkan nilai-nilai karakter. Nilai-nilai karakter yang ditanamkan seperti 
kedisiplinan, tanggung jawab, kerja keras, mandiri, jujur dan lain-lain, yang merujuk pada 18 nilai-nilai karakter yang di tetapkan oleh Kementerian Pendidikan Nasional. Penanaman nilai-nilai karakter tersebut dilakukan melalui kegiatan baris-berbaris, pertemuan, upacara, pelantikan, berkemah, dan lintas alam.

Berdasarkan uraian diatas, maka peneliti tertarik untuk melakukan penelitian yang berjudul "Implementasi Nilai-nilai karakter melalui Kegiatan Ekstrakurikuler Pramuka Di Sekolah Dasar Negeri 018 Purnama Dumai Barat Kota Dumai".

Sebagaimana yang telah dikemukakan dalam latar belakang masalah terdahulu, maka fokus penelitian ini adalah pada pelaksanaan pendidikan nilai-nilai karakter di Sekolah Dasar Negeri 018 Purnama Kecamatan Dumai Barat yang terkandung melalui kegiatan ekstrakurikuler Pramuka. Sedangkan subfokus dari penelitian ini adalah:

1. Jenis-jenis pelaksanaan kegiatan ekstrakurikuler pramuka di Sekolah Dasar Negeri 018 Purnama Dumai Barat Kota Dumai

2. Implementasi Nilai-nilai Karakter yang terkandung Melalui Kegiatan Ekstrakurikuler Pramuka di Sekolah Dasar Negeri 018 Purnama Dumai Barat Kota Dumai

3 Faktor penghambat dan solusi dalam pelaksanaan Nilai-nilai Karakter Ekstrakurikuler Pramuka di Sekolah Dasar Negeri 018 Purnama Dumai Barat Kota Dumai

Berdasarkan uraian latar belakang, fokus dan subfokus penelitian ini, maka peneliti merumuskan pertanyaan penelitian dalam penelitian ini adalah :

1. Bagaimanakah Jenis-jenis pelaksanaan kegiatan ekstrakurikuler pramuka di Sekolah Dasar Negeri 018 Purnama Dumai Barat Kota Dumai

2. Bagaimana Implementasi Nilai-nilai Karakter yang terkandung Melalui Kegiatan Ekstrakurikuler Pramuka di Sekolah Dasar Negeri 018 Purnama Dumai Barat Kota Dumai

3. Bagaimanakah Faktor penghambat dan solusi dalam pelaksanaan Nilai-nilai Karakter Ekstrakurikuler Pramuka di Sekolah Dasar Negeri 018 Purnama Dumai Barat Kota Dumai 
Secara umum tujuan penelitian ini adalah untuk menganalisa pelaksanaan pendidikan nilai-nilai karakter di Sekolah Dasar Negeri 018 Purnama Dumai Barat Kota Dumai. Secara rinci tujuan dari penelitian ini adalah:

1. Menganalisis Jenis-jenis pelaksanaan kegiatan ekstrakurikuler pramuka di Sekolah Dasar Negeri 018 Purnama Dumai Barat Kota Dumai

2. Menganalisi Implementasi Nilai-nilai Karakter yang terkandung Melalui Kegiatan Ekstrakurikuler Pramuka di Sekolah Dasar Negeri 018 Purnama Dumai Barat Kota Dumai

3. Menganalisis Faktor penghambat dan solusi dalam pelaksanaan Nilai-nilai Karakter Ekstrakurikuler Pramuka di Sekolah Dasar Negeri 018 Purnama Dumai Barat Kota Dumai

Hasil penelitian ini diharapkan dapat bermanfaat untuk mengembangkan pendidikan :

a. Sebagai bahan pertimbangan dan bahan evaluasi bagi Diknas Pendidikan khususnya deputi bidang penjamin mutu sekolah dalam menganalisa pelaksanaan pendidikan nilai-nilai karakter serta sekolah dan sebagai bahan masukan bagi Sekolah Dasar Negeri 018 Purnama Kecamatan Dumai Barat dan sekolah lainnya untuk melaksanakan Pendidikan nilai-nilai karakter dalam pembentukan karekter siswa.

b. Memberikan dorongan kepada para peserta (sekolah) yang mengikuti program pendidikan nilai-nilai karakter untuk melaksanakan program secara baik dan efektif.

\section{KAJIAN TEORETIS}

Menurut Kamus bahasa Indonesia, karakter diartikan sebagai sifat-sifat kejiwaan, akhlak, atau budi pekerti. Karakter juga dapat diartikan sebagai tabiat, yaitu perangai atau perbuatan yang selalu dilakukan atau kebiasaan (Sunyoto, 2011: 27).

Karakter berasal dari kosa kata Inggris, character. Artinya prilaku, selain character, kata lain yang berarti tingkah laku adalah attitude. Secara umum, attitude dapat dibedakan atas dua jenis, attitude baik yang disebut karakter. Attitude buruk yang disebut tabiat. Karakter merupakan kumpulan dari tingkah laku baik dari 
seorang anak manusia. Tingkah laku ini merupakan perwujudan dari kesadaran dalam menjalankan peran, fungsi dan tugasnya mengemban amanah dan tanggung jawab. Tabiat sebaliknya mengindikasi sejumlah perangai buruk seseorang (Sudewo, 2011:13).

Hal senada diungkapkan Darmiyanti Zuchdi (2008:39) dalam pembelajaran nilai karakter oleh Adsusilo memaknai karakter sebagai seperangkat sifat yang selalu dikagumi sebagai tanda-tanda kebaikan.

Pencetus pertama karakter adalah Foester, karakter menurutnya adalah sesuatu yang mengkualifikasikan seorang pribadi. Karakter menjadi identitas, menjadi ciri, menjadi sifat yang tetap, yang mengatasi pengalaman kontingen yang selalu berubah. Jadi dapat disimpulkan bahwa karakter adalah seperangkat nilai yang telah menjadi kebiasaan hidup sehingga menjadi sifat tetap dalam diri seseorang. Dengan karakter itulah kualitas seseorang dapat diukur (Adisusilo,2012:77-78)

Menurut Asmani (2011:35) pendidikan karakter merupakan upaya-upaya yang dirancang dan dilaksanakan secara sistematis untuk membantu peserta didik memahami nilai-nilai perilaku manusia yang berhubungan dengan Tuhan Yang Maha Esa, diri sendiri, sesama manusia, lingkungan dan kebangsaan. Kemudian nilai-nilai tersebut dapat terwujud dalam pikiran, sikap, perasaan, perkataan, dan perbuatan, berdasarkan norma-norma agama, hukum, tata krama, budaya dan adat istiadat.

Pendidikan karakter dapat dilakukan dengan berbagai pendekatan dan dapat berupa berbagai kegiatan yang dapat dilakukan secara intrakurikuler maupun ekstrakurikuler. Kegiatan intrakurikuler terintegrasi ke dalam mata pelajaran, sedangkan kegiatan ektrakurikuler dilakukan di luar jam pelajaran.

a. Kegiatan intrakurikuler merupakan kegiatan yang dilakukan oleh siswa, yang diintegrasikan ke dalam mata pelajaran yang relevan seperti pendidikan agama dan pendidikan kewarganegaraan. Pendidikan karakter dapat disalurkan melalui kegiatan ini. Hal ini dimaksudkan agar siswa-siswi mempunyai karakter yang baik sehingga terbentuk kepribadian yang baik pula. 
b. Kegiatan ekstrakurikuler yang selama ini diselenggarakan sekolah merupakan salah satu media yang potensial untuk pembinaan karakter dan peningkatan mutu akademik peserta didik. Kegiatan ekstrakurikuler merupakan kegiatan pendidikan di luar mata pelajaran untuk membantu pengembangan peserta didik sesuai dengan kebutuhan, potensi, bakat, dan minat mereka melalui kegiatan yang secara khusus diselenggarakan oleh pendidik dan atau tenaga kependidikan yang berkemampuan dan berkewenangan di sekolah. Melalui kegiatan ekstrakurikuler diharapkan dapat mengembangkan kemampuan dan rasa tanggung jawab sosial, serta potensi dan prestasi peserta didik (Sudrajat, 2008).

Dari pendapat-pendapat ahli diatas, dapat disintesiskan bahwa karakter merupakan tingkah laku baik seseorang yang sudah menjadi kebiasaan sehingga tertanam didalam dirinya yang dipahami sebagai stempel/cap bagaimana sifat orang tersebut, yang walaupun merupakan bawaan lahir tetapi tetap dapat berubah dan terbentuk sesuai dengan lingkungan eksternal yang dimilikinya, seperti lingkungan keluarga, sekolah, masyarakat, pergaulan dan sebagainya.

Tujuan pendidikan karakter pada dasarnya adalah mendorong lahirnya anakanak yang baik (insan kamil). Tumbuh dan berkembangnya karakter yang baik akan mendorong peserta didik tumbuh dengan kapasitas dan komitmennya untuk melakukan berbagai hal yang terbaik dan melakukan segalanya dengan benar serta memiliki tujuan hidup. Masyarakat juga berperan membentuk karakter anak melalui orang tua dan lingkungannya. Karakter dikembangkan melalui tahap pengetahuan (knowing), pelaksanaan (acting), dan kebiasaan (habit).

Kegiatan ekstrakurikuler pada dasarnya berasal dari rangkaian tiga kata yaitu: kegiatan, ekstra, dan kurikuler. Kata ekstrakurikuler berasal dari kata ekstra dan kurikuler. Ekstra berasal dari kata Extra (Inggris) yang artinya tambahan. Kurikuler berasal dari kata Curriculum (Inggris) yang artinya rencana pelajaran. Jika keduanya digabungkan "Ekstrakurikuler" berarti di luar rencana pelajaran (Echols \& Shadily, 2003: 227).

Kegiatan ekstrakurikuler merupakan kegiatan yang dilakukan diluar kelas dan diluar jam pelajaran untuk menumbuhkembangkan potensi sumber daya manusia (SDM) yang dimiliki peserta didik baik berkaitan dengan aplikasi ilmu pengetahuan 
yang didapatkannya maupun dalam pengertian khusus untuk membimbing peserta didik dalam mengembangkan potensi dan bakat yang ada dalam dirinya melalui kegiatan-kegiatan yang wajib maupun pilihan (Direktorat Jenderal Pembinaan Kelembagaan Agama Islam, 2005: 9).

Menurut Burrud yang dikutip oleh Abdurrahman (2009: 187) mengemukakan, kegiatan ekstrakurikuler adalah: variouslyreferred to as ectracuriculer, co-curiculer, or out school activitesthe are perhaps best described as ectra class or simply studentactivites. Artinya, bermacam-macam kegiatan seperti ektrakurikuler, atau kegiatan-kegiatan diluar sekolah. Kegiatan itru lebih baik digambarkan sebagai kegiatan di luar kelas hanya sebagai kegiatan-kegiatan siswa.

Menurut Sukardi (2005:243) bahwa kegiatan ekstrakurikuler adalah suatu kegiatan yang dilakukan oleh para siswa di luar jam pelajaran biasa, termasuk pada saat liburan sekolah, yang betujuan untuk memberikan pengayaan kepada peserta didik dalam artian memperluas pengetahuan peserta didik dengan cara mengaitkan pelajaran yang satu dengan pelajaran yang lainnya. Menurut Usman dan Setyowati (2003: 22) Ekstrakurikuler adalah kegiatan yang dilakukan di luar jam pelajaran (tatap muka), baik dilaksanakan di sekolah maupun di luar sekolah, dengan maksud untuk lebih memperkaya dan memperluas wawasan pengetahuan dan kemampuan yang telah dimilikinya dari berbagai bidang studi.

Secara umum kegiatan ekstrakurikuler dapat meningkatkan keterampilan interpersonal siswa. Melalui kegiatan ekstrakurikuler siswa menjalin hubungan interpersonal dengan teman sebaya anggota ekstrakurikuler yang diikuti, senior, dan pembina ekstrakurikuler. Bagi siswa yang memiliki kompetensi interpersonal rendah, pola kegiatan dan materi yang diajarkan dalam kegiatan ekstrakurikuler dapat meningkatkan penerimaan sosial dan popularitas, menurunkan alienasi sosial, mengembangkan identitas sosial dan menurunkan perilaku antisosial (Suparno, 2002: 11).

Istilah kepramukaan berasal dari kata pramuka yang merupakan kepamjangan dari "Praja Muda Karana", berarti rakyat muda yang suka berkarya. Akar kata ini mendapat awalan ke-dan akhiran -an, sehingga menjadi kata kepramukaan yang artinya suatu proses dalam bentuk kegiatan yang menyenangkan bagi anak dan pemuda di bawah tanggung jawab orang dewasa. (Poerwodarminto, 2002: 230). 
Sedangkan pengertian kepramukaan berdasarkan AD/ART Gerakan Pramuka Bab III pasal 7 ayat 1 disebutkan bahwa kepramukaan adalah proses pendidikan di luar lingkungan keluarga dalam bentuk kegiatan menarik, menyenangkan, sehat, teratur, praktis yang dilakukan di alam terbuka dengan Prinsip Dasar Kepramukaan dan Metode Kepramukaan yang sasaran akhirnya pembentukan watak, akhlak dan budi pekerti luhur.

Kepramukaan berasal dari istilah Praja Muda Karana (pramuka) yang artinya pemuda bangsa yang giat bekerja. Menurut Undang-undang Republik Indonesia No 12 Tahun 2010 pasal 1 kepramukaan adalah:

1) Gerakan Pramuka adalah organisasi yang dibentuk oleh pramuka untuk menyelenggarakan pendidikan kepramukaan

2) Pramuka adalah warga negara Indonesia yang aktif dalam pendidikan kepramukaan serta mengamalkan Satya Pramuka dan Darma Pramuka

3) Kepramukaan adalah segala aspek yang berkaitan dengan pramuka

4) Pendidikan Kepramukaan adalah proses pembentukan kepribadian, kecakapan hidup, dan akhlak mulia pramuka melalui penghayatan dan pengamalan nilai-nilai kepramukaan.

Menurut Anggaran Rumah Tangga Gerakan Pramuka (ARTGP) Tahun 2005 Pasal 7 ayat 1 kepramukaan adalah:

"Proses pendidikan yang dilakukan di luar sekolah dan di luar lingkungan keluarga dalam bentuk kegiatan yang menarik, menyenangkan, sehat, teratur, terarah, praktis, yang dilakukan di alam terbuka dengan Prinsip Dasar Kepramukaan dan Metode Kepramukaan yang sasaran akhirnya pembentukan watak, akhlak dan budi pekerti”.

Kepramukaan adalah suatu permainan yang menyenangkan di alam terbuka yang mengandung pendidikan, tempat orang-orang dewasa dan anak-anak pergi bersama-sama, mengadakan pengembaraan bagaikan kakak beradik, membina kesehatan dan kebahagiaan, keterampilan dan kesediaan untuk memberi pertolongan bagi yang membutuhkannya (Sunardi, 2006: 3).

Kegiatan kepramukaan merupakan kegiatan yang dilaksanakan untuk mencapai tujuan Gerakan Pramuka, kegiatan harus mengarah pada sasaran pendidikan kepramukaan yaitu pengembangan dan pembinaan watak, mental, I. Sufriani, Z. Saam. \& Caska, Implementasi Nilai-nilai Karakter 
jasmani, rokhani, pengetahuan, pengalaman dan keterampilan pramuka (Abbas dkk, 1994: 154).

\section{METODOLOGI PENELITIAN}

\section{Tempat dan Waktu Penelitian}

Penelitian ini dilakukan di Sekolah Dasar Negeri 018 Purnama yang beralamat: Jalan Raja Ali Haji Gg. Sekolah Kecamatan Dumai Barat Kota Dumai Provinsi Riau. Lama penelitian ini berlangsung sejak Juli 2020 sampai Januari 2021. Secara formal kegiatan ini di lakukan pada pagi hingga siang tepatnya pada jam - jam sekolah.

Berdasarkan uraian diatas maka yang yang menjadi sumber data penelitian ini adalah sebagai berikut:

1. Sumber data primer: (a) kegiatan ekstrakurikuler pramuka di lingkungan Sekolah Dasar Negeri 018 Purnama Kecamatan Dumai Barat Kota Dumai yang dilaksanakan oleh Pembina dan siswa (b) Kepala Sekolah, (c) Wakil Kepala Sekolah, (d) Komite Sekolah, (e) Pengawas Sekolah, (f) Guru pembimbing pramuka dan siswa sebagai peserta kegiatan ekstrakurikuler pramuka di Sekolah Dasar Negeri 018 Purnama Dumai Barat Kota Dumai.

2. Sumber data sekunder antara lain: Arsip dan dokumen berupa arsip-arsip foto, dokumen perorangan, dokumen resmi, dan dokumen lainnya yang berkaitan dengan focus dan subfokus penelitian yaitu pelaksanaan Pendidikan karakter Di Sekolah Dasar Negeri 018 Purnama Dumai Barat Kota Dumai.

Pengumpulan data dilakukan melalui wawancara, dokumentasi dan observasi.

\section{Wawancara}

Wawancara dilakukan pada key informan yang nantinya akan memberikan infromasi lebih rinci tentang pelaksanaan program pendidikan berkarakter di Sekolah Dasar Negeri 018 Purnama Kecamatan Dumai Barat Kota Dumai yaitu Kepala sekolah, Wakil kepala sekolah, guru, komite sekolah pengawas sekolah, siswa dan orangtua siswa di Sekolah Dasar Negeri 018 Purnama Kecamatan Dumai Barat Kota Dumai tersebut.

2. Dokumentasi 
Dokumensi yang menjadi bahan bukti fisik yang diperlukan baik berupa foto seperti piala penghargaan, foto slogan dan poster maupun foto kegiatan siswa di Sekolah Dasar Negeri 018 Purnama KecamatanDumai Barat Kota Dumai .

\section{Pengamatan}

Tujuan peneliti melakukan pengamatan/observasi adalah untuk memperoleh secara langsung pelaksanaan pendidikan karakter dalam pembentukan perilaku siswabaik yang sifatnya kontinu atau kondisional.

Peran peneliti dalam situs observasi adalah sebagai pengamat implementasi karakter melalui kegiatan ekstrakurfikuler yang dilaksanakan di Sekolah Dasar Negeri 018 Purnama Kecamatan Dumai Barat Kota Dumai. Pengamatan/Observasi akan dilakukan di Sekolah Dasar Negeri 018 Purnama Kecamatan Dumai Barat Kota Dumai tersebut.

Observasi berlangsung pada saat jam sekolah dan luar sekolah yang sifatnya terkoordinir, terencana, terawasi secara baik dari sekolah.

Penelitian ini yaitu penelitian kualitatif, maka analisis data dilakukan saat pelaksanaan penelitian, baik langsung dilakukan pada saat pengambilan data maupun setelah data terkumpul.

Analisis data dalam penelitian ini dengan langkah - langkah sebagai berikut:

1. Reduksi Data

2. Penyajian Data

3. Penarikan Kesimpulan dan Verifikasi

Untuk menjaga keabsahan data serta perolehan hasil yang dapat dipertanggung jawabkan, maka peneliti mengacu pada data - data yang diberikan para informan penelitian. Keabsahan data yang diperoleh peneliti dengan cara:

1. Melakukan wawancara secara mendalam dengan informan penelitian yang berbeda, yaitu Kepala sekolah, Wakil kepala sekolah, guru, komite sekolah, pengawas sekolah, siswa dan orangtua siswa di Sekolah Dasar Negeri 018 Purnama Kecamatan Dumai Barat Kota Dumai.

2. Membandingkan hasil wawancara mendalam dari beberapa informan.

3. Menghubungkan data yang diperoleh melalui pengamatan mendalam dengan hasil wawancara dalam menarik sebuah kesimpulan. 
4. Memeriksa kesesuaian hasil analisis data dan dapat saling menjelaskan satu dengan yang lain, sehingga hasil penelitian dapat dipercaya.

5. Memeriksa kembali kesesuaian hasil dan kesimpulan hasil penelitian dengan apa yang telah diperoleh dari informan dan partisipan dalam penelitian.

\section{HASIL DAN PEMBAHASAN}

\section{Hasil Penelitian}

Dalam bagian ini, peneliti menguraikan data dan temuan penelitian selama penelitian ini berlangsung mengenai implementasi pendidikan karakter melalui kegiatan ekstrakurikuler pramuka di Sekolah Dasar Negeri 018 Purnama Dumai Barat Kota Dumai. Dengan demikian uraian data dan temuan penelitian terdapat tiga komponen utama sesuai dengan focus kajian penelitian diantaranya meliputi: Jenisjenis pelaksanaan kegiatan pramuka, Implementasi Nilai-nilai Karakter yang terkandung Melalui Kegiatan Ekstrakurikuler Pramuka dan Faktor Penghambat dan Solusi dalam Implementasi Nilai-nilai Karakter Melalui Kegiatan Ekstrakurikuler Pramuka di Sekolah Dasar Negeri 018 Purnama Dumai Barat Kota Dumai.

\section{Jenis-Jenis Pelaksanaan Kegiatan Ekstrakurikuler Pramuka di Sekolah Dasar Negeri 018 Purnama Dumai Barat Kota Dumai.}

Maka dalam mewujudkan hal tersebut, Gerakan Pramuka SDN 018 Purnama melaksanakan kegiatan kepramukaan. Dimana kegiatan tersebut dilaksanakan dalam bentuk latihan mingguan dan partisipasi kegiatan di luar Gudep SDN 018 Purnama. Diharapkan dengan dilaksanakan kegiatan kepramukaan ini para peserta didik (generasi penerus bangsa) bisa mempersiapkan dirinya untuk menghadapi perkembangan di masa mendatang.

Dibawah ini adalah jenis-jenis pelaksanaan kegiatan ekstrakurikuler pramuka:

1. Pekemahan sabtu minggu (persami)

2. Tali temali

3. Peraturan baris berbaris (PBB)

4. Peonering 


\section{Implementasi Nilai-nilai Karakter yang terkandung Melalui Kegiatan Ekstrakurikuler Pramuka}

Pendidikan Kepramukaan di Indonesia merupakan salah satu segi pendidikan nasional yang penting, yang merupakan bagian dari sejarah perjuangan bangsa Indonesia, gerakan pramuka Indonesia adalah nama organisasi pendidikan nonformal yang menyelenggarakan pendidikan kepanduan yang dilaksanakan di Indonesia.

Jika kita hubungkan dalam Pendidikan karakter bangsa yang bersumber pada Agama, Pancasila, Budaya dan Tujuan Pendidikan Nasional teridentifikasi 18 Nilai karakter, dan ternyata bila kita cermati dari 18 nilai tersebut juga merupakan bentuk pengamalan satya dan dharma pramuka. Nilai tersebut antara lain:

1. Religius, Sikap dan perilaku yang patuh dalam melaksanakan ajaran agama yang dianutnya, toleran terhadap pelaksanaan ibadah agama lain, dan hidup rukun dengan pemeluk agama lain. (merupakan bentuk pengamalan dharma ke 1. Takwa kepada Tuhan yang maha esa)

2. Jujur, Perilaku yang didasarkan pada upaya menjadikan dirinya sebagai orang yang selalu dapat dipercaya dalam perkataan, tindakan, dan pekerjaan. (merupakan bentuk pengamalan dharma ke 10. Suci dalam fikiran perkataan dan perbuatan)

3. Toleransi, Sikap dan tindakan yang menghargai perbedaan agama, suku, etnis, pendapat, sikap, dan tindakan orang lain yang berbeda dari dirinya. (merupakan bentuk pengamalan dharma ke 1. Takwa kepada Tuhan yang maha esa)

4. Disiplin, Tindakan yang menunjukkan perilaku tertib dan patuh pada berbagai ketentuan dan peraturan. (merupakan bentuk pengamalan darma ke 8 . Disiplin Berani dan setia)

5. Demokratis, Cara berfikir, bersikap, dan bertindak yang menilai sama hak dan kewajiban dirinya dan orang lain. (merupakan bentuk pengamalan darma ke 4 . Patuh dan suka bermusyawarah)

6. Semangat Kebangsaan, Cara berpikir, bertindak, dan berwawasan yang menempatkan kepentingan bangsa dan negara di atas kepentingan diri dan 
kelompoknya (merupakan bentuk pengamalan darma ke 3. Patriot yang sopan dan ksatria)

7. Cinta Tanah Air, cara berfikir, bersikap, dan berbuat yang menunjukkan kesetiaan, kepedulian, dan penghargaan yang tinggi terhadap bahasa, lingkungan fisik, sosial, budaya, ekonomi, dan politik bangsa. (merupakan bentuk pengamalan darma ke 3 . Patriot yang sopan dan ksatria)

8. Peduli Lingkungan, Sikap dan tindakan yang selalu berupaya mencegah kerusakan pada lingkungan alam di sekitarnya, dan mengembangkan upayaupaya untuk memperbaiki kerusakan alam yang sudah terjadi. (merupakan bentuk pengamalan darma ke 2. Cinta alam dan kasih sayang sesama manusia)

9. Peduli Sosial, Sikap dan tindakan yang selalu ingin memberi bantuan pada orang lain dan masyarakat yang membutuhkan. (merupakan bentuk pengamalan darma ke 2. Cinta alam dan kasih sayang sesama manusia)

10. Tanggung-jawab, Sikap dan perilaku seseorang untuk melaksanakan tugas dan kewajibannya, yang seharusnya dia lakukan, terhadap diri sendiri, masyarakat, lingkungan (alam, sosial dan budaya), negara dan Tuhan Yang Maha Esa. (merupakan bentuk pengamalan darma ke 9. bertanggung jawab dan dapat dipercaya)

Setelah peneliti melakukan observasi dokumentasi di Sekolah Dasar Negeri 018 Purnama Dumai Barat Kota Dumai, sekolah telah melaksanakan pendidikan karakter melalui kegiatan pramuka, seperti contoh dalam kegiatan pramuka yang peneliti temukan saat melakukan observasi di Sekolah Dasar Negeri 018 Purnama Dumai Barat Kota Dumai. Pembina pramuka menerapkan nilai-nilai karakter dalam pelaksanaan kegiatannya. Pembina menerapkan kedisiplinan, tanggung jawab, jujur, berjiwa sosial tinggi, dan peduli akan lingkungan sekitar. Semua nilai-nilai karakter ini tidak hanya di terapkan dalam latihan kepramukaan siswa namun juga diterapkan dalam kegiatan belajar siswa setiap harinya, seperti kedisiplinan dengan melaksanakan sholat berjamaah setiap harinya, makan bersama teratur dikantin sekolah, melatih kepedulian dengan merujuk siswa yang sakit kerumah atau kerumah sakit dan gotong royong dalam membersihkan lokal atau pekarangan sekolah. 
Nilai-nilai yang diterapkan dalam pelaksanaan kegiatan ekstrakurikuler pramuka di Sekolah Dasar Negeri 018 Purnama Dumai Barat Kota Dumai merupakan cerminan dari nilai-nilai karakter. Seperti dokumentasi yang peneliti dapatkan ketika observasi di Sekolah Dasar Negeri 018 Purnama Dumai Barat Kota Dumai dalam kegiatan pramuka diterapkan nilai kedisiplinan dan tanggung jawab.

Dibawah ini merupakan contoh implementasi nilai-nilai karakter yang terkandung dalam kegiatan ekstrakurikuler pramuka.

1. Disiplin dan tanggung jawab dalam menempati jadwal pelajaran menempati jadwal pelajaran yang sudah ditentukan memang kadang-kadang siswa sangat sulit, terkadang pembelajaran di mulai pukul 07.30 tapi masih ada siswa yang terlambat dalam penerimaan materi dan tugas.

2. Disiplin dan tanggung jawab dalam menghargai waktu perihal waktu merupakan sesuatu yang sangat penting dalam kehidupan, setiap orang harus bisa menggunakan waktu sebaik-baiknya. Karena waktu tidak akan berputar kembali

3. Disiplin dan Tanggung jawab terhadap diri sendiri melalui kegiatan pramuka siswa dibentuk karakter disiplin dan tanggung jawab terhadap diri sendiri.

4. Disiplin dan Tanggung Jawab dalam menjaga kondisi fisik. Disiplin dan tanggung jawab dalam menjaga kesehatan atau kondisi fisik juga ini juga dibekali dalam kegiatan pramuka. Selain pola disiplin dan tanggung jawab yang lainnya. Kegiatan pramuka juga membiasakan anak untuk menjaga pola hidup sehat.

\section{Faktor Penghambat dan Solusi Dalam Pelaksanaan Nilai-Nilai Karakter}

\section{Ekstrakurikuler Pramuka}

Berdasarkan observasi yang penulis lakukan di Sekolah Dasar Negeri 018 Purnama Dumai Barat Kota Dumai terdapat beberapa kendala dalam pelaksanaan kegiatan pramuka, diantaranya motivasi siswa rendah untuk mengikuti kegiatan pramuka, terlihat saat observasi kegiatan pramuka yang peneliti lakukan. Pada saat peneliti melakukan observasi dan menemui dokumentasi absenssi kegiatan pramuka siswa pada bulan juli dan agustus tahun 2018 sebenarnya dijadwalkan 2 kelas dari kelas 4 dan 2 kelas dari kelas 3 Sekolah Dasar Negeri 018 Purnama 
Dumai Barat Kota Dumai yang dijumlahkan sekitar 115 siswa, namun yang datang hanya berjumlah 63 orang siswa, selanjutnya faktor orang tua murid mereka tidak merasa apa-apa jika anak mereka tidak mengikuti kegiatan pramuka, karena merasa kegiatan pramuka tidak begitu penting bagi anak-anak mereka dengan materi yang itu-itu saja.

Selain itu masalah sarana dan prasarana selalu menjadi tajuk utama dalam pelaksanaan kegiatan pramuka sebab sekolah hanya sarana dan prasarana yang ada di sekolah untuk kegiatan pramuka, sehingga Pembina hanya bisa menyesuaikan program dengan prasarana yang ada. Serta kurangnya pengetahuan dan pengalaman Pembina dalam kegiatan pramuka.

Peran serta guru yang lain, karyawan sekolah dan komite untuyk meningkatkan kegiatan pramuka kurang menunjukkan semangat. Hal ini terbukti dari kurangnya karyawan dan komite sekolah meliobatkan diri dalam kegiatan ekstrakurikuler sekolah.

\section{Temuan Penelitian}

\section{Sub fokus Jenis-Jenis Pelaksanaan Kegiatan Pramuka di Sekolah Dasar Negeri 018 Purnama Dumai Barat Kota Dumai}

1. Program Kegiatan Ekstrakurikuler Pramuka Selama Dua Tahun Terakhir

Berdasarkan peraturan dan perencanaan kegiatan ektrakurikuler pramuka di Sekolah Dasar Negeri 018 Purnama Dumai Barat Kota Dumai, sekolah telah memiliki program kegiatan ektrakurikuler yang mana program tersebut dibuat sesuai dengan aturan yang berlaku.

Program diatur sesuai dengan kebutuhan sekolah dalam rangka menerapkan nilai-nilai pendidikan karakter dalam kegiatan pramuka. Rancangan kegiatan pramuka yang dibuat sekolah telah dijalankan selama dua tahun terakhir. Peneliti dapat menjabarkan karena mendapatkan akses yang mudah untuk mendapatkan informasi dan dokumentasi mengenai pelaksanaan program ekstrakurikuler karena keterbukaan informasi oleh kepala Sekolah Dasar Negeri 018 Purnama Dumai Barat Kota Dumai. 
Sesuai dengan wawancara peneliti dengan Ibu Sumarni S.Pd kepala Sekolah Dasar Negeri 018 Purnama Dumai Barat Kota Dumai, pada tanggal 15 Februari 2021 tentang program kegiatan ekstrakurikuler pramuka selama dua tahun terakhir.

Selanjutnya untuk keabsahan data peneliti wawancarai Ibu Rahma S.Pd pembina pramuka Sekolah Dasar Negeri 018 Purnama Dumai Barat Kota Dumai pada tanggal 17 februari 2021 tentang penyusunan perencanaan.

2. Pelaksanaan Kegiatan Pramuka Di Sekolah Dasar Negeri 018 Purnama Dumai Barat Kota Dumai

Berdasarkan hasil tela'ah dokumentasi berupa pengelolaan kegiatan ekstrakurikuler di Sekolah Dasar Negeri 018 Purnama Dumai Barat Kota Dumai maupun instrumen, sekolah tersebut melaksanakan program ektrakurikuler pramuka dengan baik. Kepala sekolah sebagai penanggung jawab kegiatan ektrakurikuler pramuka telah mempersiapakan pembina untuk kegiatan ekstrakurikuler pramuka.

Untuk melaksanakan program pramuka sekolah tentu harus mempersiapakan tenaga ahli yang kompeten dan mengerti dalam bidang pramuka sebagai pembina, agara kegiatan pramuka dapat berjalan dengan baik dan terarah sesuai dengan tujuan dilaksanakannya kegiatan pramuka tersebut. Para pembina pramuka ini terdiri dari guru-guru sekolah itu sendiri ataupun darti luar sekolah. Jika sekolah mempersiapkan tenaga pembina dari dalam sekolah maka harus mengisnstruksikan pembina untuk mengikuti pelatihan-pelatihan pembina pramuka.

Hal ini sesuai dengan hasil wawancara peneliti dengan lbu Sumarni S.Pd kepala Sekolah Dasar Negeri 018 Purnama Dumai Barat Kota Dumai, pada tanggal 15 Februari 2021.

\section{Menanamkan nilai-nilai karakter bagi siswa Sekolah Dasar 018 Purnama}

Menanamkan nilai-nilai karakter merupakan tujuan utama dari pelaksanaan kegiatan ekstrakurikuler pramuka. Dari hasil kegiatan ini tentu saja di harapkan adanya hasil yang menujukan arah atau buah dari pelaksanan kegiatan ekstrakurikuler tersebut.

Seperti halnya hasil wawancara peneliti dengan kepala Sekolah Dasar Negeri 018 Purnama Dumai Barat Kota Dumai yaitu ibu Sumarni pada tanggal 15 Februari. 
Sejalan dengan apa yang di ungkapkan kepala sekolah pembina pramuka Sekolah Dasar Negeri 018 Purnama Dumai Barat Kota Dumai yaitu Ibu Rahma S.Pd pada tanggal 17 februari 2021.

Kemudian wawan cara peneliti dengan salah satu wali kelas Sekolah Dasar Negeri 018 Purnama Dumai Barat Kota Dumai yaitu ibu Dona Purnama Sarai pada tanggal 17 Februari 2021.

Demi keabsahan penelitian, kemudian wawancara peneliti lakukan dengan salah satu wali murid yaitu Ibu Misnika pada tanggal 17 februari 2021 mengenai nilai-nilai karakter yang di tanamkan dalam pramuka

Salah seorang siswa yang mengikuti kegiatan pramu turut peneliti wawancarai yaitu Fizila pada tanggal 17 februari 2021.

4. Kegiatan pramuka yang dapat menanamkan nilai-nilai karakter

Berdasarkan hasil tela'ah dokumentasi, observasi serta wawancara peneliti dalam kegiatan pramuka yang dapat menanamkan nilai-nilai karakter di Sekolah Dasar Negeri 018 Purnama Dumai Barat Kota Dumai, kepala sekolah memberikan instruksi untuk pembina agar melakukan berbagai cara agar tertanamnya nilai-nilai karakter pada siswa walaupun itu secara perlahan.

Seperti hasil wawancara peneliti dengan kepala sekolah yaitu Ibu Sumarni S.Pd pada tanggal 15 Februari 2021 mengenai kegiatan pramuka yang dapat menanamkan nilai-nilai karakter, seperti yang di ungkapkan oleh ibu kepala sekolah.

Sejalan dengan yang diungkapkan oleh kepala Sekolah Dasar Negeri 018 Purnama Dumai Barat Kota Dumai, pembina pramuka Sekolah Dasar Negeri 018 Purnama Dumai Barat Kota Dumai yaitu Ibu Rahma S.Pd pada tanggal 17 Februari 2021, beliau juga mengungkapkan hal yang senada.

Demi keabsahan penelitian, penaliti turut mewawancairai ibu Donna Purnama Sari S.Pd selaku wali kelas Sekolah Dasar Negeri 018 Purnama Dumai Barat Kota Dumai.

5. Strategi yang dilakukan dalam penyampaian materi dalam kegiatan Pramuka Berdasarkan tela'ah hasil dokumentasi dan observasi yang penulis lakukan di Sekolah Dasar Negeri 018 Purnama Dumai Barat Kota Dumai dalam meneliti I. Sufriani, Z. Saam. \& Caska, Implementasi Nilai-nilai Karakter 
kegiatan pramuka, penyampaian materi terus dilakukan dalam oleh pembina pramuka dalam kegiatan pramuka atas instruksi dari kepala sekolah. Namun durasi materi yang diberikat hanya singkat dan pemberian materipun dilakukan saat dilaksanakannya kegiatan seperti saat bermain ataupun berkegiatan lainnya.

Pemberian materi tentu terus diberikan oleh Pembina pramuka kepada anggota pramuka untuk selalu ikut serta dan terlibat aktif dalam kegiatan pramuka.

Seperti yang di sampaikan oleh kepala sekolah Sekolah Dasar Negeri 018 Purnama Dumai Barat Kota Dumai yaitu Ibu Sumarni S.Pd pada tanggal 15 februari 2021.

Demi keabsahan penalitian, peneliti turut mewawancarai pembina pramuka Sekolah Dasar Negeri 018 Purnama Dumai Barat Kota Dumai yaitu Ibu Siti Rahma S.Pd pada tanggal 17 februari 2021. Tidak jauh berbeda apa yang diungkapkan beliau dibandingkan dengan apa yang di sampaikan oleh kepala Sekolah Dasar Negeri 018 Purnama Dumai Barat Kota Dumai.

\section{Implementasi Nilai-nilai Karakter yang Terkandung Melalui Kegiatan}

\section{Esktrakurikuler Pramuka}

1. Nilai Kedisiplinan

Dalam pelaksanaan kegiatan pramuka di Sekolah Dasar Negeri 018 Purnama Dumai Barat Kota Dumai, kepala sekolah selaku pimpinan menitik beratkan karater seperti kedisiplinan yang disisipkan dalam setiap kegiatan yang di adakan. Nilai kedisiplinan ini sangat penting untuk membentuk karakter siswa. Seperti yang diungkapkan oleh kepala Sekolah Dasar Negeri 018 Purnama Dumai Barat Kota Dumai yaitu Ibu Sumarni S.Pd pada tanggal 15 Februari 2021.

Demi keabsahan peneliatan, peneliti turut mewawancarai pembina pramuka Sekolah Dasar Negeri 018 Purnama Dumai Barat Kota Dumai,yaitu ibu Siti Rahma S.Pd pada tanggal 17 Februari 2021.

2. Nilai tanggung jawab

Kemudian tanggung jawab menjadi karakter pendukung utama terbentuknya karater siswa. Untuk itu nilai tanggung jawab ini menjadi materi yang wajib yang 
disisipkan dalam setiap kegiatan pramuka di Sekolah Dasar Negeri 018 Purnama Dumai Barat Kota Dumai.

Seperti yang di ungkapkan oleh kepala Sekolah Dasar Negeri 018 Purnama Dumai Barat Kota Dumai yaitu lbu Sumarni S.Pd pada tanggal 15 februari 2021, saat peneliti wawancarai.

Demi keabsahan penilitian ini, peneliti turut mewawancarai pembina Sekolah Dasar Negeri 018 Purnama Dumai Barat Kota Dumai, yaitu ibu Siti Rahma S.Pd tanggal 17 Februari 2021.

\section{Faktor Penghambat dan Solusi dalam Pelaksanaan Nilai-nilai Karakter}

\section{Esktrakurikuler Pramuka}

1. Faktor penghambat dalam pelaksanaan

Dari hasil wawancara peneliti dengan kepala Sekolah Dasar Negeri 018 Purnama Dumai Barat Kota Dumai, dapat di simpulkan bahwasanya tetap ada berbagai hambatan yang di alami dalam melaksanakan kegiatan pramuka di Sekolah Dasar Negeri 018 Purnama Dumai Barat Kota Dumai, seperti yang di ungkapkan oleh ibu Sumarni S.Pd pada tanggal 15 Februari 2021, yakni, masalah penganggaran yang minim dan sarana/prasarana yang terbatas. tenaga Pembina dan dapat juga dikatakan kurangnya pengalaman Pembina.

Sejalan dengan yang di ungkapkan kepala sekolah, pembina pramuka Sekolah Dasar Negeri 018 Purnama Dumai Barat Kota Dumai yaitu Ibu Siti Rahma S.Pd juga mengungkapkan hal yang hampir sama,

Sama seperti disampaikan Pembina pramuka Sekolah Dasar Negeri 018 Purnama Dumai Barat Kota Dumai juga mengungkapkan hambatan apa saja yang di hadapi dalam melaksanakan kegiatan pramuka.

Selanjutnya dari apa yang di Ungkapakan oleh kepala Sekolah Dasar Negeri 018 Purnama Dumai Barat Kota Dumai, peneliti kembali menanyakan salah seorang wali kelas yaitu ibu Dona Purnama Sari S.Pd pada tanggal 17 Februari 2021 mengenai hambatan yang sering di temui dalam pelaksanaan kegiatan pramuka. Kendalanya sarana prasarana seperti lapangan yang sempit dan ada sebagian yang becek, apabila cuaca hujan, siswa latihannya tidak bisa dilapangan. 
Demi keabsahan penelitian ini, peneliti turut mewawancarai seorang wali murid yaitu ibu Maskina pada tanggal 17 Februari 2021 mengenai kendala kegiatan pramuka ini, belaiu mengungkapkan seperti berikut: Halaman sekolah sempit dan ada yang becek jadi hambatan untuk anak melakukan kegitan dilapangan

Kemudian wawancara dengan salah satu murid Sekolah Dasar Negeri 018 Purnama Dumai Barat Kota Dumai yaitu Fazila mengenai hambatan dalam kegiatan pramuka, sama seperti disampaikan ibu maskina.

2. Solusi dalam pelaksanaan kegiatan pramuka di Sekolah Dasar Negeri 018 Purnama Dumai Barat Kota Dumai

Berdasarkan wawancara peneliti dengan kepala Sekolah Dasar Negeri 018 Purnama Dumai Barat Kota Dumai pada tanggal 15 februari 2021 mengenai upaya atau solusi apa saja yang dilakukan guna meminimalisir hambatan yang terjadi dalam pelaksanaan kegiatan pramuka, pihak sekolah melakukan rapat mencari solusi atas masalah yang dihadapi, kita kan melibatakan orang tua murid dan juga komite dalam mencari jawaban atas hambatan yang dihadapi ini.

Demi keabsahan penelitian ini, peneliti turut mewawancarai pembina pramuka Ibu Dona Purnama Sari S.Pd Sekolah Dasar Negeri 018 Purnama Dumai Barat Kota Dumai, tentang upaya yang dilakukan dalam meminimalisir hambatan dalam melaksanakan kegiatan pramuka. Sama seperti disebutkan kepala sekolah.

Kemudian pembina pramuka Sekolah Dasar Negeri 018 Purnama Dumai Barat Kota Dumai pada tanggal 17 Februari 2021 mengungkapkan cara yang dapat dilakukan guna menanggulangi hambatan dalam melaksanakan kegiatan pramuka. Senada dengan yang disampaikan kepala sekolah.

Sejalan dengan itu wali kelas Sekolah Dasar Negeri 018 Purnama Dumai Barat Kota Dumai yaitu Ibu dona Purnama Sari S.Pd mengungkapakan sedikit upaya yang dilakukan selama ini dalam meminimalisir hambatan dalam kegiatan pramuka, seperti berikut : Agar latihan mingguannya tetap berjalan lancar, kami meminjam lapangan olah raga milik kampus UNRI karena gedung UNRI yang di Dumai berhadapan atau tidak jauh denga sekolah kami. 


\section{Pembahasan Peneltian}

Pada bagian ini peneliti akan menguraikan pembahasan tentang temuan penelitian mengenai "Implementasi Nilai-nilai Karakter yang terkandung Melalui Kegiatan Ekstrakurikuler Pramuka di Sekolah Dasar Negeri 018 Purnama Dumai Barat Kota Dumai", adapun bagian-bagian yang dibahas pada bab ini disesuaikan dengan focus penelitian yang meliputi: a) Jenis-jenis pelaksanaan kegiatan ekstrakurikuler pramuka di Sekolah Dasar Negeri 018 Purnama Dumai Barat Kota Dumai, b) Implementasi Nilai-nilai Karakter yang terkandung Melalui Kegiatan Ekstrakurikuler Pramuka, dan c) Faktor penghambat dan solusi dalam pelaksanaan Nilai-nilai Karakter Ekstrakurikuler Pramuka.

\section{Jenis-jenis Pelaksanaan Kegiatan Eksatrakurikuler pramuka di Sekolah Dasar Negeri 018 Purnama Dumai Barat Kota Dumai}

Berdasarkan paparan bab IV diatas, maka yang harus dilihat sebagai berikut: (1) Program Kegiatan Ekstrakurikuler Pramuka Selama Dua Tahun Terakhir dan (2) Pelaksanaan Kegiatan Pramuka di Sekolah Dasar Negeri 018 Purnama Dumai Barat Kota Dumai, (3) Menanamkan nilai-nilai karakter bagi siswa Sekolah Dasar Negeri 018 Purnama, (4) kegiatan pramuka yang dapat menanamkan nilai-nilai karakter, dan (5) Strategi yang dilakukan dalam penyampaian materi dalam kegiatan Pramuka.

1. Program Kegiatan Ekstrakurikuler Pramuka dalam pelaksanaan kegiatan pramuka di Sekolah Dasar Negeri 018 Purnama Dumai Barat Kota Dumai Selama Dua Tahun Terakhir

Secara sistematis Sekolah Dasar Negeri 018 Purnama Dumai Barat Kota Dumai telah membuat program kegiatan pramuka jangka panjang (1 tahun) bahkan dalam kurun waktu dua tahun terakhir program kepramukaan itu telah dijalankan walaupun belum ada perbaikan yang dilakukan dari tahun sebelumnya.

2. Pelaksanaan Kegiatan Pramuka Di Sekolah Dasar Negeri 018 Purnama Dumai Barat Kota Dumai 
Berkaitan dengan hal tersebut pengurus ekstrakurikuler pramuka di Sekolah Dasar Negeri 018 Purnama Dumai Barat Kota Dumai telah menetapkan sasaran langkah-langkah dalam mewujudkan kegiatan bidang kepramukaan sebagai wadah penyaluran bakat, hobi, keterampilan dan pembentukkan karakter dalam kegiatan kepramukaan sehingga siswa diharapkan dapat mengembangkan potensi dalam dirinya terutama binaan karakter.

Sekolah mempersiapkan para pembina pramuka yang diharapkan mampu mengemban tugas ini dengan baik. Sekolah menginstruksikan para guru agar dapat mengikuti berbagai klegiatan dan pelatihan pembina pramuka. Dengan ini nantinya diharapkan sekolah dapat melahirkan pembina-pembina pramuka yang handal dan menguasai bidang kepramukaan dengan baik. Dengan kemampuan yang dimiliki pembina pramuka Sekolah Dasar Negeri 018 Purnama Dumai Barat Kota Dumai, maka akan menjadikan kegiatan pramuka ini sebagai kegiatan yang dapat membentuk dan memberikan nilai-nilai karakter pada siswa.

3. Menanamkan nilai-nilai karakter bagi siswa Sekolah Dasar Negeri 018 Purnama melalui Kegiatan Ekstrakurikuler Pramuka

Menanamkan nilai-nilai karakter dalam pelaksanaan kegiatan pramuka menjadi hal utama yang di lakukan di Sekolah Dasar Negeri 018 Purnama Dumai Barat Kota Dumai. Namun dengan berbagai keterbatasan baik tenaga ahli ataupun pembina sekolah lebih menitik beratkan pada pembina pramuka untuk memasukkan nilai karakter riligious, kearifan, peduli lingkungan ,demokratis dan komunikatif pada setiap kegiatan pramuka yang dilaksanakan.

4. Kegiatan pramuka yang dapat menanamkan nilai-nilai karakter

Peran serta Dewan Kerja Pramuka Penegak dan Pandega dalam hal ini adalah membantu mensukseskan pelaksanaan kegiatan dengan memberikan arahan, peninjauan dan materi pendukung sebagai awal pengenalan kegiatan dan pola pembinaan yang baru bagi adik-adik Pramuka Penggalang.

Memberikan pengarahan dapat dilakukan disaat pengenalan atau penerimaan anggota baru ataupun disaat pembekalan pramuka untuk mengadakan kegiatan diluar maupun didalam sekolah. 
Dengan berbagai kegiatan ini seperti membagi kelompok kegiatan akan memberikan pemahaman pada siswa bagaimana berkumpul, berbagi dan bekerja sama dengan baik.

5. Strategi yang dilakukan dalam penyampaian materi dalam kegiatan Pramuka di Sekolah Dasar Negeri 018 Purnama Dumai Barat Kota Dumai

Membina pramuka merupakan kegiatan memperkenalkan, menumbuhkan, dan mengembangkan:

a. Kepribadian (kualitas nilai),

b. Pengetahuan dan keterampilan,

c. Minat, keinginan, bakat serta kemampuan, peserta didik sehingga menjadi manusia yang: kreatif, inovatif, pelopor dan mandiri.

Ini membuat seorang Pembina pramuka memililiki peran, tugas dan tanggung jawab yang sangat besar dalam proses pembinaan itu. Peran dan tanggung jawab yang besar terkadang menurunkan tingkat motivasi Pembina terlebih mereka selalu berhadapan dengan anggota yang bisa dikatakan awam mengenai kepramukaan.

Hal seperti ini telah dilakukan di Sekolah Dasar Negeri 018 Purnama Dumai Barat Kota Dumai, artinya sekolah sangat memperhatikan hidup dan terjalinnya hubungan dan komunikasi antara pembina pramuka dan siswa. Yang pada akhirnya akan memberikan efek positif bagi kegiatan dan siswa itu sendiri.

\section{Implementasi Nilai-nilai Karakter yang terkandung Melalui Kegiatan Ekstrakurikuler Pramuka di Sekolah Dasar Negeri 018 Purnama Dumai Barat Kota Dumai}

1. Nilai Kedisiplinan dalam pelaksanaan kegiatan pramuka di Sekolah Dasar Negeri 018 Purnama Dumai Barat Kota Dumai

Untuk membangun nilai-nilai kedisiplinan dalam kegiatan pramuka Sekolah Dasar Negeri 018 Purnama Dumai Barat Kota Dumai, selalu mengabsensi siswa sebelum dan setelah kegiatan dilakukan guna siswa dapat datang dan pulang dengan teratur. Setiap kegiatan pramuka yang dilaksanakan harus dilakukan tepat waktu untuk membangun kedisiplinan siswa agar tidak datang terlambat. Kemudian setiap siswa yang tiudak mengikuti dan berpakaian lengkap akan diberikan sangsi atas kesalahan mereka sendiri agar. Aturan ini telah dilaksanan selama dua tahun 
terakhir kegiatan pramuka di Sekolah Dasar Negeri 018 Purnama Dumai Barat Kota Dumai.

2. Nilai Tanggung jawab dalam pelaksanaan kegiatan pramuka di Sekolah Dasar Negeri 018 Purnama Dumai Barat Kota Dumai

Kemudian untuk meningkatkan nilai tanggung jawab siswa dalam kegiatan pramuka yang di adakan oleh Sekolah Dasar Negeri 018 Purnama Dumai Barat Kota Dumai, setiap siswa dibagi atas kelompok kegiatan tersebut. Dan setiap kelompok akan diberiakn tugas-tugas tertentu yang harus di laksanakan oleh setiap anggota kelompok dengan baik.

Maka dengan metode ini di harapkan terbagun jiwa-jiwa bertanggung jawab dalam diri siswa setelah mengikuti kegiatan pramuka di Sekolah Dasar Negeri 018 Purnama Dumai Barat Kota Dumai.

Faktor penghambat dan solusi dalam pelaksanaan Nilai-nilai Karakter Ekstrakurikuler Pramuka di Sekolah Dasar Negeri 018 Purnama Dumai Barat Kota Dumai

Berdasarkan diatas, maka dapat dibahas hasil temuan penelitian tentang faktor penghambat dalam pelaksanaan nilai-nilai karakter ekstrakurikuler pramuka di Sekolah Dasar Negeri 018 Purnama Dumai Barat Kota Dumai sebagai berikut : (1) Faktor penghambat dalam pelaksanaan Ekstrakurikuler Pramuka di Sekolah Dasar Negeri 018 Purnama Dumai Barat Kota Dumai, dan (2) Solusi dalam pelaksanaan kegiatan pramuka di Sekolah Dasar Negeri 018 Purnama Dumai Barat Kota Dumai, semua dibahas sebagai berikut :

1. Faktor penghambat dalam pelaksanaan Ekstrakurikuler Pramuka di Sekolah Dasar Negeri 018 Purnama Dumai Barat Kota Dumai

Disisi lain dari pihak siswa banyak yang kurang berminat terhadap kegiatan pramuka. Hal ini disebabkan orientasi belajar siswa terfokus pada orientasi nilai pada pelajaran-pelajaran umum terutama pelajaran yang diujikan, sehingga siswa menganggap kegiatan pramuka sebagai kegiatan tambahan yang kurang penting. Padahal di balik kesederhanaan pramuka tersebut dapat mengantarkan siswa pada 
pengembangan potensi (life skill) yang dimiliki siswa berkaitan dengan nilai-nilai yang terkandung dalam Dasa darma Pramuka (Nurul Hidayah, 2010: 4).

Seperti yang ditemui peneliti melalui dokumentasi dan observasi di Sekolah Dasar Negeri 018 Purnama Dumai Barat Kota Dumai kekurangan pembina, motivasi siswa untuk mengikuti kegiatan pramuka dan sarana prasarana yang kurang mendukung menjadi masalah yang setiap semesternya harus dihadapi sekolah dalam pelaksanaan kegiatan pramuka.

2. Solusi dalam pelaksanaan kegiatan pramuka di Sekolah Dasar Negeri 018 Purnama Dumai Barat Kota Dumai

Hal yang paling penting selanjutnya ialah pemberian pelatihan pramuka dan penambahan jumlah pembina pramuka agar kegiatan ini semakin baik dan tidak kekurangan Pembina.

\section{SIMPULAN}

Berdasarkan temuan penelitian dan pembahasan tentang Implementasi Nilainilai Karakter Melalui Kegiatan Ekstrakurikuler Pramuka di Sekolah Dasar Negeri 018 Purnama Dumai Barat Kota Dumai, dapat disimpulkan:

1. Dari aspek Jenis-jenis pelaksanaan kegiatan ekstrakurikuler, dalam pelaksanaan kegiatan ekstrakurikuler prsamuka Sekolah Dasar Negeri 018 Purnama Dumai Barat Kota Dumai telah melakukan tahap-tahap kegiatan yang tentu saja bertjuan untuk penanaman nilai-nilai karater siswa dalam kegiatan pramuka tersebut. Kegiatan ini pun mendapat dukungan penuh dari sekolah dan kepala sekolah karena merasa kegiatan ini sangatlah penting bagi siswa. Beberapa hal yang telah dilakukan dan dimiliki dalam pelaksanaan kegiatan pramuka di Sekolah Dasar Negeri 018 Purnama Dumai Barat Kota Dumai pramuka diantaranya: a). Program Kegiatan Ekstrakurikuler Pramuka Selama Dua Tahun Terakhir, b) Pelaksanaan Kegiatan Pramuka, c) Menanamkan nilai-nilai karakterdalam kegiatan pramuka, d) kegiiatan pramuka yang dapat menanamkan nilai-nilai karakter, dan e) Strategi yang dilakukan dalam penyampaian materi dalam kegiatan Pramuka. Dari hasil analisis data yang dilakukan pada dampak kegiatan pramuka dalam 
membentuk karakter disiplin dan tanggung jawab yaitu reward dan punishmemt, perintah dan arahan secara langsung, serta pengkondisian pada setiap Tindakan

2. Dari aspek Implementasi Nilai-nilai Karakter yang terkandung Melalui Kegiatan Ekstrakurikuler Pramuka, peneliti menemui beberapa hal diantaranya: a) Menanamkan Nilai Kedisiplinan dalam pelaksanaan kegiatan pramuka di Sekolah Dasar Negeri 018 Purnama Dumai Barat Kota Dumai dan (2) Menanamkan Nilai Tanggung jawab dalam pelaksanaan kegiatan pramuka di Sekolah Dasar Negeri 018 Purnama Dumai Barat Kota Dumai. Hal ini dibuktikan dengan tercapainya 4 indikator disiplin dan tanggung jawab dalam menepati jadwal pelajaran seperti mengerjakan tugas-tugas yang diberikan, disiplin dan tanggung jawab dalam menghargai waktu, siswa tidak menunda-nunda pekerjaan terutama ibadah, disiplin dan tanggung jawab terhadap diri sendiri berfokus pada sikap kemandirian siswa dan disiplin dan tanggung jawab dalam menjaga kondisi fisik yaitu siswa sudah dapat menjaga pola hidup yang sehat.

3. Dari aspek faktor penghambat dan solusi dalam pelaksanaan Nilai-nilai Karakter Ekstrakurikuler Pramuka di Sekolah Dasar Negeri 018 Purnama Dumai Barat Kota Dumai peneliti menemui beberapa hal diantaranya: a) Faktor penghambat (1) kurangnnya tenaga ahli dalam bidang pramuka (2) rendahnya dukungan dari wali murid (3) kurangnya sarana dan prasarana pramuka di sekolah dan (4) rendahnya minat siswa dalam pelaksanaan Ekstrakurikuler Pramuka di Sekolah Dasar Negeri 018 Purnama Dumai Barat Kota Dumai, dan (2) Solusi dalam pelaksanaan kegiatan pramuka di Sekolah Dasar Negeri 018 Purnama Dumai Barat Kota Dumai (1) memberikan pelatihan secara professional bagi Pembina pramuka (2) memberikan pemahaman pentinya pendidikan karakter melalui kegiatan pramuka bagi wali murid dan (3) mingkatkan anggaran kegiatan sekolah untuk pramuka. 


\section{SARAN}

Dari hasil penelitian tentang Implementasi Nilai-nilai Karakter Melalui Kegiatan Ekstrakurikuler Pramuka di Sekolah Dasar Negeri 018 Purnama Dumai Barat Kota Dumai, maka peneliti menyampaikan beberapa saran sebagai berikut:

1. Agar kiranya tetap mempertahankan dan lebih meningkatkan lagi kualitas pelaksanaan kegiatan pramuka karena hasi penelitian mnunjukkan bahwa kegiatan pramuka terbukti mampu memberikan kontribusi yang kuat dalam membentuk karakter disiplin dan tanggung jawab siswa

2. Sekolah Dasar Negeri 018 Purnama Dumai Barat Kota Dumai, agar selalu meningkatkan kualitas pendidikan karakter terutama mencari reliabel dan valid dalam mengukur efektifitas program ekstrakurikuler pramuka yang dilaksanakan dalam membentuk karakter siswa.

3. Sekolah Dasar Negeri 018 Purnama Dumai Barat Kota Dumai merupakan sekolah yang tanggap perubahan bangsa yang pesat. Oleh karenanya tidak imbang jika komponen yang wajib ada di sekolah terlebih kekurangan Pembina pramuka yang berkualitas menjadi penghambat bagi siswa untuk berprestasi dalam kegiatan pramuka untuk itu diharapkan terus memberikan pelatihan khusus bagi Pembina agar semakin memahami dan meningkatakan kemampuan dalam pelatihan pramuka.

\section{DAFTAR PUSTAKA}

Abbas, A., dkk. (1994). Pedoman Lengkap Gerakan Pramuka. Semarang: Beringin Jaya.

Abdurrahman, M. (2009). Pendidikan Bagi Anak Berkesulitan Belajar. Jakarta: Rineka Cipta.

Adisusilo, S. (2012). Pembelajaran Nilai-Karakter. Jakarta: PT. Raja Grafindo Persada.

Asmani, J. M. (2011). Buku Panduan Internalisasi Pendidikan Karakter di Sekolah. Jogjakarta: Diva Press

Echols, J. M., \& Shadily, H. (2003). Kamus Inggris Indonesia. Jakarta: Gramedia. 
Murniyetti, M., Engkizar, E., \& Anwar, F. (2016). Pola pelaksanaan pendidikan karakter terhadap siswa sekolah dasar. Jurnal Pendidikan Karakter, 6(2), 156166.

Nuh, M. (2013). kepramukaan ditetapkan sebagai kegiatan ekstrakurikuler wajib dari sekolah dasar (SD/MI) hingga sekolah menengah atas (SMA/SMK).

Poerwadarminta W. J. S. (2002). Kamus Besar Bahasa Indonesi. Jakarta: Balai Pustaka.

Putra, M. J. A., \& Hermaya, V. (2020). Primary School Students' Discipline through Scouting. Journal of Teaching and Learning in Elementary Education, 3(1), 69-76.

Sudewo E. (2011). Best Practice Character Building : Menuju Indonesia Lebih Baik. Jakarta : Republika Penerbit.

Sudrajat, A. (2008). Pengertian, Strategi, Metode, Teknik, dan Model. Pembelajaran. Bandung: Sinar Baru Algensindo.

Sukardi, D. K. (2002). Pengantar Pelaksanaan Program Bimbingan dan Konseling di Sekolah. Jakarta : Rineka Cipta.

Sunardi, A. B. (2006). Boyman, Ragam Latih Pramuka. Bandung: Nuansa. Muda.

Sunyoto, Sanyonto. (2011). Analisis Regresi untuk Uji Hipotesis. Yogyakarta: Caps.

Suparno, Y. M. (2002). Keterampilan Dasar menulis. Jakarta : Universitas Terbuka.

Usman, M. U., \& Setyowati, L. (2003). Upaya Optimalisasi Kegiatan Belajar. Mengajar. Bandung: Remaja Rosdakarya.

Yuliana, Y., Putra, M. J. A., \& Antosa, Z. (2020). Faktor-Faktir yang Mempengaruhi Motivasi Siswa Sekolah Dasar dalam Mengikuti Aktivitas Pramuka Penggalang. Tunjuk Ajar: Jurnal Penelitian IImu Pendidikan, 3(2), 210-226. 